University of Nebraska - Lincoln

DigitalCommons@University of Nebraska - Lincoln

\title{
Net Global Warming Potential and Greenhouse Gas Intensity in Irrigated Cropping Systems in Northeastern Colorado
}

Arvin R. Mosier

University of Florida

Ardell D. Halvorson

USDA-ARS

Curtis A. Reule

USDA-ARS

Xuejun J. Liu

China Agricultural University

Follow this and additional works at: https://digitalcommons.unl.edu/usdaarsfacpub

Part of the Agricultural Science Commons

Mosier, Arvin R.; Halvorson, Ardell D.; Reule, Curtis A.; and Liu, Xuejun J., "Net Global Warming Potential and Greenhouse Gas Intensity in Irrigated Cropping Systems in Northeastern Colorado" (2006).

Publications from USDA-ARS / UNL Faculty. 271.

https://digitalcommons.unl.edu/usdaarsfacpub/271

This Article is brought to you for free and open access by the U.S. Department of Agriculture: Agricultural Research Service, Lincoln, Nebraska at DigitalCommons@University of Nebraska - Lincoln. It has been accepted for inclusion in Publications from USDA-ARS / UNL Faculty by an authorized administrator of DigitalCommons@University of Nebraska - Lincoln. 


\title{
Net Global Warming Potential and Greenhouse Gas Intensity in Irrigated Cropping Systems in Northeastern Colorado
}

\author{
Arvin R. Mosier, Ardell D. Halvorson,* Curtis A. Reule, and Xuejun J. Liu
}

\begin{abstract}
The impact of management on global warming potential (GWP), crop production, and greenhouse gas intensity (GHGI) in irrigated agriculture is not well documented. A no-till (NT) cropping systems study initiated in 1999 to evaluate soil organic carbon (SOC) sequestration potential in irrigated agriculture was used in this study to make trace gas flux measurements for 3 yr to facilitate a complete greenhouse gas accounting of GWP and GHGI. Fluxes of $\mathrm{CO}_{2}, \mathrm{CH}_{4}$, and $\mathrm{N}_{2} \mathrm{O}$ were measured using static, vented chambers, one to three times per week, year round, from April 2002 through October 2004 within conventional-till continuous corn (CT-CC) and NT continuous corn (NT-CC) plots and in NT corn-soybean rotation (NT-CB) plots. Nitrogen fertilizer rates ranged from 0 to $224 \mathrm{~kg} \mathrm{~N} \mathrm{ha}^{-1}$. Methane fluxes were small and did not differ between tillage systems. Nitrous oxide fluxes increased linearly with increasing $\mathbf{N}$ fertilizer rate each year, but emission rates varied with years. Carbon dioxide efflux was higher in CT compared to NT in 2002 but was not different by tillage in 2003 or 2004. Based on soil respiration and residue $C$ inputs, NT soils were net sinks of GWP when adequate fertilizer was added to maintain crop production. The CT soils were smaller net sinks for GWP than NT soils. The determinant for the net GWP relationship was a balance between soil respiration and $\mathrm{N}_{2} \mathrm{O}$ emissions. Based on soil $\mathrm{C}$ sequestration, only NT soils were net sinks for GWP. Both estimates of GWP and GHGI indicate that when appropriate crop production levels are achieved, net $\mathrm{CO}_{2}$ emissions are reduced. The results suggest that economic viability and environmental conservation can be achieved by minimizing tillage and utilizing appropriate levels of fertilizer.
\end{abstract}

$\mathrm{C}$ ONVERTING atmospheric $\mathrm{CO}_{2}$ into stable organic carbon pools in the soil can sequester $\mathrm{CO}_{2}$, while commonly used crop production practices generate $\mathrm{CO}_{2}$ and $\mathrm{N}_{2} \mathrm{O}$ and decrease the soil sink for atmospheric $\mathrm{CH}_{4}$. The overall balance between the net exchange of these gases constitutes the net global warming potential (GWP) of a crop production system (Robertson and Grace, 2004). Typically agricultural soils vary from being minor emitters of $\mathrm{CH}_{4}$ to small sinks for atmospheric $\mathrm{CH}_{4}$ (Bronson and Mosier, 1993). Nitrous oxide, the

A.R. Mosier, Agricultural and Biological Engineering Department, University of Florida, 281 Frazier Rogers Building, Museum Road, P.O. Box 110570, Gainesville, FL 32611. A.D. Halvorson and C.A. Reule, USDA-ARS, 2150 Centre Avenue, Building D, Suite 100, Fort Collins, CO 80526-8119. X.J. Liu, College of Resources and Environmental Sciences, China Agricultural University, Beijing, China. Contribution from USDA-ARS, Fort Collins, CO. The U.S. Department of Agriculture offers its programs to all eligible persons regardless of race, color, age, sex, or national origin, and is an equal opportunity employer. Mention of trade names or proprietary products does not indicate endorsement by USDA and does not imply its approval to the exclusion of other products that may be suitable. Received 10 June 2005. *Corresponding author (ardell.halvorson@ars.usda.gov).

Published in J. Environ. Qual. 35:1584-1598 (2006). Special Submissions

doi:10.2134/jeq2005.0232 principal non- $\mathrm{CO}_{2}$ greenhouse gas emitted from soils, is produced naturally in the soil through nitrification and denitrification. Nitrogen fertilizer input to facilitate crop production augments this production. It is the relationship of soil $\mathrm{C}$ changes relative to $\mathrm{N}_{2} \mathrm{O}$ emissions that typically regulates net GWP (Robertson et al., 2000).

Carbon dioxide emissions from fossil fuel combustion contribute approximately $50 \%$ of total GWP globally, while $\mathrm{CH}_{4}(16 \%)$ and $\mathrm{N}_{2} \mathrm{O}(5 \%)$ contribute about $20 \%$ to GWP from all sources (Intergovernmental Panel on Climate Change, 2001). Globally, anthropogenic sources of $\mathrm{N}_{2} \mathrm{O}$ and $\mathrm{CH}_{4}$ are dominated by agriculture and sum to 7.7 $\mathrm{Pg} \mathrm{CO}_{2}$ equivalents $\mathrm{yr}^{-1}$ (Robertson and Grace, 2004); this is close to the annual global atmospheric loading rate for $\mathrm{CO}_{2}$ of $8.4 \mathrm{Pg} \mathrm{CO}_{2} \mathrm{yr}^{-1}$ (Intergovernmental Panel on Climate Change, 2001). In the United States, $\mathrm{CO}_{2}$ emitted from farming (approximately $50 \mathrm{Tg}$ ), $\mathrm{N}_{2} \mathrm{O}$ emitted in crop and livestock production (approximately $300 \mathrm{Tg}$ ), $\mathrm{CH}_{4}$ emitted from livestock production (approximately 160 $\mathrm{Tg}$ ), and increased soil C storage (approximately $-60 \mathrm{Tg}$ ) sum to approximately $450 \mathrm{Tg}$ of $\mathrm{CO}_{2}$ equivalents annually (USEPA, 2002). The net emission of $\mathrm{CO}_{2}$ equivalents from farming activities can potentially be decreased by changing management to increase soil organic matter content (Follett, 2001) and decrease $\mathrm{N}_{2} \mathrm{O}$ emissions (Kroeze et al., 1999). Changing from CT to NT practices typically leads to increased soil organic carbon (SOC) content in the surface $7.5 \mathrm{~cm}$ of soil with little change observed below that depth (West and Post, 2002).

No-till management of soils has been promoted as a practice that off-sets the GWP from emissions of $\mathrm{N}_{2} \mathrm{O}$ and $\mathrm{CH}_{4}$ in crop production because of its ability to sequester carbon in the soil (Cole et al., 1997; Council for Agricultural Science and Technology, 2004). In a recent analysis of available field data, Six et al. (2004) found that systems that were recently converted to NT increased GWP relative to CT practices in both humid and dry climates. After more than $10 \mathrm{yr}$ under NT, cumulative GWP was reduced in both humid and dry climates. Emissions of $\mathrm{N}_{2} \mathrm{O}$ drive much of the trend in net GWP. The limited number of data sets that are available for such analyses, and the high uncertainty associated with the $\mathrm{N}_{2} \mathrm{O}$ flux data, dictate a high uncertainty to the GWP data. The decrease in $\mathrm{N}_{2} \mathrm{O}$ flux with time that a system has been in NT in the Six et al. (2004) analysis is attributed to increased soil aggregation and improved aeration status. During the first few years of NT, soil bulk density in the top $30 \mathrm{~cm}$ may increase, but as SOC accumulates over time, soil structure improves as more stable aggregates

\footnotetext{
Abbreviations: CT, conventional-till; CT-CC, conventional-till continuous corn; GHGI, greenhouse gas intensity; GWP, global warming potential; NT, no-till; NT-CB, no-till corn-soybean rotation; NT-CC, no-till continuous corn; SOC, soil organic carbon.
} 
develop, and soil aeration improves concomitantly (Six et al., 2004). The resulting effect is a decrease in net GWP over time in dry and humid climate soils.

A very different picture of the effect of time under NT on GWP is given in a modeling study. Using the DAYCENT ecosystem model, Del Grosso et al. (2002) observed that during the first few years of NT, the soil decreased net GWP. Over time, as the rate of increase in SOC declined and $\mathrm{N}_{2} \mathrm{O}$ emissions increased because of increased $\mathrm{N}$ availability, the net GWP increased relative to CT soils. The increase in GWP could be minimized by decreasing $\mathrm{N}$ fertilizer input while maintaining yield. This simulation suggests that the impact of NT on net GWP decreases over time in a dry agroecosystem. During the first 12-yr period, the change in SOC is greatest and $\mathrm{N}_{2} \mathrm{O}$ emissions are lowest (Del Grosso et al., 2002). Over time, the rate of $\mathrm{C}$ sequestration declines and $\mathrm{N}_{2} \mathrm{O}$ emissions increase because the rate of immobilization of inorganic $\mathrm{N}$ declines. The model predicted that the small soil $\mathrm{CH}_{4}$ sink declines under NT because of higher soil water content. Changes in $\mathrm{CH}_{4}$ consumption are small, however, and have little impact on net GWP estimates as demonstrated by the Robertson et al. (2000) field study. The DAYCENT model does not account for changes in soil structure following conversion to NT but does allow uniform conditions for all comparisons.

The data used in the Six et al. (2004) evaluation are, in contrast, from a variety of studies that were likely conducted using a variety of methodologies. As a result, the relative importance of improved soil structure on decreasing $\mathrm{N}_{2} \mathrm{O}$ emission suggested by the array of field studies and the DAYCENT model projection of increased $\mathrm{N}_{2} \mathrm{O}$ emissions over time cannot be fully evaluated at this time.

Another concept for relating agricultural practices to GWP is greenhouse gas intensity (GHGI). This term relates GWP to crop yield and is calculated by dividing GWP by crop yield (grain yield for corn). A positive GHGI number indicates a net source of $\mathrm{CO}_{2}$ equivalents per $\mathrm{kg}$ of yield and a negative value indicates net sinks of $\mathrm{GHG}$ to the soil. Little is known about the effects of tillage and crop rotation on GHGI.

We initiated studies in 2002 to provide data to assist in DAYCENT model verification. These studies were imposed on an existing tillage, $\mathrm{N}$ rate, and cropping system study that began in 1999 to examine the effects of these management variables on GWP and GHGI in irrigated cropping systems. The objectives were to obtain a multicalendar year set of data that included crop production, climate, and trace gas flux data that could be used to support ecosystem process simulation modeling. This paper presents the full data set collected over the period of April 2002 through October 2004. Part of the April 2002-March 2003 data was presented in Mosier et al. (2005) and the $\mathrm{N}_{2} \mathrm{O}$ flux data for 2003-2004 were discussed in Liu et al. (2005).

\section{MATERIALS AND METHODS Site Description}

The tillage by $\mathrm{N}$ rate experiment was initiated in 1999 at the Agricultural Research Development and Education Center
(ARDEC) in northeastern Colorado near the city of Fort Collins $\left(40^{\circ} 39^{\prime} \mathrm{N}, 104^{\circ} 59^{\prime} \mathrm{W}\right.$; $1530 \mathrm{~m}$ above mean sea level). The region has a semiarid temperate climate with typical mean temperature of $10.6^{\circ} \mathrm{C}$ and rainfall of $382 \mathrm{~mm} \mathrm{yr}^{-1}$ (the average of 1900-2003). Corn (Zea mays L.), wheat (Triticum aestivum L.), and barley (Hordeum vulgare L.) are the main crops in local agriculture. The soil is a Fort Collins clay loam classified as fine-loamy, mixed, superactive, mesic Aridic Haplustalfs. The field was in CT continuous corn for $6 \mathrm{yr}$ before the experiment. Selected chemical and physical properties of the soil at a 0 - to $15-\mathrm{cm}$ depth, sampled in October 2002, are reported in Table 1.

\section{Experimental Design and Management}

A randomized factorial experimental block with three replicates was established, with two tillage systems (CT-CC, conventional-till continuous corn; NT-CC, no-till continuous corn; and NT-CB, no-till corn-soybean rotation) and three $\mathrm{N}$ rates: 0,134 , and $202 \mathrm{~kg} \mathrm{~N}^{-1}$ in 2002 and $0,67,134$, and $224 \mathrm{~kg} \mathrm{~N} \mathrm{ha}^{-1}$ in 2003 and 2004. Mechanical tillage was used in the CT-CC plots (stalk shredder, disk, moldboard plow, rollermulcher [two passes], land leveler [two passes]) for seed bed preparation. The residue was left on the soil surface of the NT$\mathrm{CC}$ and NT-CB plots after harvest without mechanical tillage. Fertilizer $\mathrm{N}$ as urea ammonium nitrate (UAN) solution (containing 32\% N) was injected to about $5 \mathrm{~cm}$ below the soil surface in bands spaced $33 \mathrm{~cm}$ apart just before planting corn in late April each year. Besides basal N application, a subsurface band application of phosphorus (0-46-0) was applied at a rate of $56 \mathrm{~kg} \mathrm{P} \mathrm{ha}^{-1}$ before planting in 1999 and $28 \mathrm{~kg} \mathrm{P} \mathrm{ha} \mathrm{h}^{-1}$ in 2004 for both CT and NT systems. Liquid starter fertilizer containing $\mathrm{P}, \mathrm{K}$, and $\mathrm{S}$ was applied to the seed row at planting in 2000, 2002, 2003, and 2004. A lateral move sprinkler irrigation system was used to apply water. Herbicides were used for weed control in all treatments, resulting in the plots being essentially weed-free. Biomass samples were collected in mid- to late September each year for determination of crop residue production. Grain yields were measured at physiological maturity in late October to early November each year by hand harvesting two rows $7.6 \mathrm{~m}$ long per plot. Plot management details for the study are provided in Halvorson et al. (2004, 2006).

\section{Methane, Carbon Dioxide, and Nitrous Oxide Flux Measurements}

Measurement of the soil-atmosphere exchange of $\mathrm{CH}_{4}, \mathrm{CO}_{2}$, and $\mathrm{N}_{2} \mathrm{O}$ began in April 2002 (Liu et al., 2005; Mosier et al., 2005). Measurements were made one to three times per week, year-round, midmorning of each sampling day. Ten-centimeterhigh vented rectangular aluminum chambers were placed in a water channel that was welded onto anchors $(78.6 \times 39.3 \times$

Table 1. Selected soil chemical and physical properties of the study site.

\begin{tabular}{lccccccc}
\hline Treatment $\dagger$ & $\begin{array}{c}\text { Bulk } \\
\text { density }\end{array}$ & SOC $\ddagger$ & $\begin{array}{c}\text { Total soil } \\
\text { N }\end{array}$ & pH & EC $\S$ & Sand & Clay \\
\hline & g cm $^{-3}$ & $\mathrm{~g} \mathrm{~kg}^{-1}$ & $\mathrm{~g} \mathrm{~kg}^{-1}$ & & $\mathrm{mS} \mathrm{cm}^{-1}$ & \multicolumn{2}{c}{$\mathbf{g ~ k g}^{-1}-$} \\
CT-CC & $\mathbf{1 . 3 6}$ & $\mathbf{1 1 . 9}$ & $\mathbf{1 . 4 7}$ & $\mathbf{7 . 7}$ & $\mathbf{1 . 0 0}$ & $\mathbf{4 0 2}$ & $\mathbf{3 3 4}$ \\
NT-CC & $\mathbf{1 . 2 8}$ & $\mathbf{1 2 . 8}$ & $\mathbf{1 . 5 2}$ & $\mathbf{7 . 7}$ & $\mathbf{0 . 9 5}$ & $\mathbf{4 0 2}$ & $\mathbf{3 3 4}$ \\
NT-CB & $\mathbf{1 . 4 7}$ & $\mathbf{1 3 . 8}$ & $\mathbf{1 . 3 7}$ & $\mathbf{7 . 8}$ & $\mathbf{0 . 9 1}$ & $\mathbf{4 0 2}$ & $\mathbf{3 3 4}$ \\
\hline
\end{tabular}

$\uparrow$ CT-CC, conventional-till continuous corn; NT-CB, no-till corn-soybean rotation; NT-CC, no-till continuous corn.

† Soil organic carbon.

$\S$ Electrical conductivity. 
$10 \mathrm{~cm}$ that were inserted $10 \mathrm{~cm}$ into the soil) at each sampling. Anchors were set perpendicular to the corn row so that the corn row and inter-row were contained within each chamber. Anchors were removed for tillage and planting operations and reinstalled near the initial locations. Duplicate flux measurements were made within each replicate of each treatment plot for a total of six measurements per treatment. Gas samples from inside the chambers were collected by syringe at 0,15 , and $30 \mathrm{~min}$ after installation. Gas samples $(25 \mathrm{~mL}$ to ensure over pressure of sample in the tubes) were then injected into 12-mL evacuated tubes that were sealed with butyl rubber septa and transported to the laboratory in Fort Collins for analysis by gas chromatography. The gas chromatograph used was a fully automated instrument (Model 3800; Varian, Palo Alto, CA) equipped with thermoconductivity, flame ionization, and electron capture detectors to quantify $\mathrm{CO}_{2}, \mathrm{CH}_{4}$, and $\mathrm{N}_{2} \mathrm{O}$, respectively (Mosier et al., 2005). Fluxes were calculated from the linear or nonlinear increase in concentration (selected according to the emission pattern) in the chamber headspace with time (Livingston and Hutchinson, 1995).

\section{Ancillary Measurements}

Soil water content and soil and air temperature were monitored continuously at selected sites and at each trace gas sampling event using time domain reflectrometry (TDR; Mosier et al., 2002) in 2002 and soil dielectric constant (Decagon Devices, Pullman, WA) in 2003 and 2004. Soil samples $(0-15 \mathrm{~cm})$ were collected several times during each corn growing season and were analyzed for mineral $\mathrm{N}$ (ammonium and nitrate) using a continuous flow analyzer (QuikChem FIA + 8000 Series; Lachat Instruments, Loveland, CO) after extraction with $1 \mathrm{M} \mathrm{KCl}$ (soil to solution ratio = 1:5). The total soil $\mathrm{C}$ was measured by dry combustion on 0 - to 7.5-cm depth air-dried soils. Soil inorganic $\mathrm{C}$ was determined using the method of Sherrod et al. (2002). The difference between total soil $\mathrm{C}$ and soil inorganic $\mathrm{C}$ was the estimated SOC concentration. Soil bulk density was used to convert SOC concentration to a mass basis. The date and amount of precipitation and irrigation were also recorded at the site during the study period.

\section{Statistical Analysis}

Differences in gas fluxes by tillage, $\mathrm{N}$ rate, and year were determined statistically (ANOVA and GLM regressions) using MINITAB (Release 13 for Windows; Minitab, 2001) and Statistix 8.0 (Analytical Software, 2005). Significant differences are expressed at $P<0.05$, unless otherwise stated.

\section{RESULTS AND DISCUSSION Temperature and Water}

Averaged across the entire 30-mo observation period, soil temperature did not differ by tillage, $\mathrm{N}$ rate, or crop rotation. However, during March-July of each year, soil temperature was significantly $(P<0.05)$ higher $\left(1-3^{\circ} \mathrm{C}\right)$ in CT soils compared to NT soils (Fig. 1B). The same amount of irrigation was applied to CTand NT treatments and we assume that precipitation was uniform across the experimental plots (Fig. 2A and 2B). Averaged across the three growing seasons, volumetric water content (Fig. 2C) was higher $(1-5 \%)$ in NT soils compared to CT. No significant differences were observed with $\mathrm{N}$ rate or crop rotation within NT treatments.

\section{Trace Gas Fluxes}

\section{Methane}

Neither tillage nor $\mathrm{N}$ rate significantly influenced $\mathrm{CH}_{4}$ flux $(P>0.2)$. Soils were typically small sinks or small sources of $\mathrm{CH}_{4}$, depending on the timing of sampling relative to irrigation or precipitation, except during the first two to three months of the 2002 growing season. During this period surface soils $(0-10 \mathrm{~cm})$ were kept very wet in attempt to moisten the very dry soil profile below. Little precipitation was received during the autumn of 2001, and winter and early spring of 2002 . During this time the soils of all plots served as small sources of $\mathrm{CH}_{4}$ to the atmosphere (Fig. 3; Table 2).

During the 2002 growing season all plots were a net source of $\mathrm{CH}_{4}$ to the atmosphere. Flux rates were not significantly different $(P>0.2)$ across tillage, $\mathrm{N}$ rate, or crop rotations. In 2003 and 2004 (Fig. 4A) most plots were small net sinks for atmospheric $\mathrm{CH}_{4}$, with no significant differences $(P>0.1)$ observed with tillage, $\mathrm{N}$ rate, or crop rotation. During the fallow or non-cropped seasons (Fig. 4B), November-April 2002-2003 and 2003-2004, all plots acted as small net sinks of atmospheric $\mathrm{CH}_{4}$. There were no significant differences across all treatments.

Intensification of agricultural practices in the shortgrass steppe decreased the soil sink for atmospheric $\mathrm{CH}_{4}$ (Bronson and Mosier, 1993). Conversion of grassland and other native systems to agricultural uses has been shown to decrease the soil uptake of atmospheric $\mathrm{CH}_{4}$ in a variety of other climate zones as well (Chan and Parkin, 2001; Kessavalou et al., 1998; Robertson et al., 2000). Notillage cropping systems may have the potential to at least partially remediate crop production-related decreases in soil $\mathrm{CH}_{4}$ consumption as Kessavalou et al. (1998), Hutsch (1998), and Robertson et al. (2000) found small increases in $\mathrm{CH}_{4}$ consumption under NT. However, Chan and Parkin (2001) did not observe enhanced $\mathrm{CH}_{4}$ consumption in NT soils compared to plowed soils. We also did not observe an enhancement of $\mathrm{CH}_{4}$ consumption in NT soils. Possibly, the length of time that a field has been in NT influences the activity of the microbial populations responsible for $\mathrm{CH}_{4}$ consumption. The soils in our study were converted from conventional moldboard plow cultivation to NT in 1999 . The NT practices in the Robertson et al. (2000) and Kessavalou et al. (1998) studies were instituted more than 10 and $20 \mathrm{yr}$, respectively, before the gas flux measurements while the Hutsch (1998) soils had been in NT much longer.

Like the earlier observations (e.g., Bronson and Mosier, 1993; Chan and Parkin, 2001), cultivated fields can serve as small sinks or small sources of $\mathrm{CH}_{4}$ depending on soil water conditions (Fig. 3 and 4; Table 2). Also, as observed earlier in cropped fields located near Fort Collins, application of $\mathrm{N}$ did not appear to have an inhibitory effect on $\mathrm{CH}_{4}$ consumption (Bronson and Mosier, 1993; Delgado and Mosier, 1996). This is in contrast to the apparent decrease in $\mathrm{CH}_{4}$ consumption in shortgrass steppe soils that had been $\mathrm{N}$ fertilized (Mosier et al., 1991). We also did not observe distinct seasonality in $\mathrm{CH}_{4}$ consumption rates 



Fig. 1. (A) Daily minimum and maximum air temperature at the field site, April 2002-October 2004; and (B) soil temperature at a 5-cm depth, measured at the time of each gas flux measurement. Note the different temperature scales.

(Fig. 4A and 4B). Fluxes typically ranged between +2 and $-2 \mu \mathrm{g} \mathrm{CH} \mathrm{CH}_{4}-\mathrm{C} \mathrm{m}^{-2} \mathrm{~h}^{-1}$ in both summer and winter.

\section{Carbon Dioxide}

During the soybean phase of the NT-CB rotation (2003) the soybeans were not removed from the gas flux measurement area because we wanted to measure the effect of growing soybeans on $\mathrm{N}_{2} \mathrm{O}$ emissions. As a result, plant respiration was included in the $\mathrm{CO}_{2}$ flux measurements during the growing season (Fig. 5A and 5C). During the corn growing season in 2002, corn plants were maintained within the flux chamber area until August. In 2003 and 2004 corn plants were removed by cutting the plants off at the soil surface and removing them from the flux measurement area in early July (Fig. 5A, $5 \mathrm{~B}$, and $5 \mathrm{C}$ ). Soil respiration typically closely follows changes in soil temperature with maximum fluxes during 



Fig. 2. (A) Precipitation and (B) irrigation at the field site, and (C) volumetric soil water content measured at the time of each gas flux measurement.

the warmest part of the year and minimum fluxes during the coldest parts of the year. Even when soil temperature was below $0^{\circ} \mathrm{C}, \mathrm{CO}_{2}$ fluxes were measurable.

The $\mathrm{CO}_{2}$ exchange rates can be directly compared for CT-CC and NT-CC across all three years, but in NT-CB only during the 2002 and 2004 growing seasons when corn was growing and during the fallow periods, because soybeans were not removed from the gas measurement area during the 2003 growing season (Fig. 5A; Table 2). During 2002, $\mathrm{CO}_{2}$ flux rates were significantly greater from CT soils than NT soils $(P<0.01)$ (Fig. 6A). There were no significant differences with $\mathrm{N}$ rate. Within the



Fig. 3. Soil-atmosphere $\mathrm{CH}_{4}$ exchange observations from 28 Apr. 2002 until 28 Oct. 2004 in (A) plots to which no fertilizer $\mathbf{N}$ was applied, (B) plots to which $134 \mathrm{~kg} \mathrm{~N} \mathrm{ha}^{-1}$ fertilizer $\mathrm{N}$ was applied, and (C) plots fertilized with $202 \mathrm{~kg} \mathrm{~N} \mathrm{ha}^{-1}$ in 2002 and $224 \mathrm{~kg} \mathrm{~N}$ $\mathrm{ha}^{-1}$ in 2003 and 2004. Note the different scales for $\mathrm{CH}_{4}$ flux.

NT treatments $\mathrm{CO}_{2}$ fluxes did not differ with crop rotation $(P>0.2)$. Although $\mathrm{CO}_{2}$ fluxes tended to be higher in 2002 than in 2003 or 2004, within the NT treatment they were not significantly different across years $(P>0.1)$. Growing season $\mathrm{CO}_{2}$ fluxes averaged slightly higher from NT soils than the CT soils in both 2003 (not statistically significant, $P=0.29$ ) and 2004 $(P=0.026)$ (Fig. 6A).

Soil $\mathrm{CO}_{2}$ flux was significantly greater $(P<0.01)$ in CT than in NT during the 2002-2003 fallow season (Fig. 6B). The CT soils were plowed in early January 2003, and $\mathrm{CO}_{2}$ fluxes increased greatly immediately 
Table 2. Annual trace gas exchange as affected by tillage, $\mathbf{N}$ fertilization, and crop rotation. $\dagger$

\begin{tabular}{|c|c|c|c|c|c|c|}
\hline \multirow[b]{2}{*}{ Treatment $\neq$} & \multicolumn{2}{|c|}{$\mathbf{C H}_{4}$} & \multicolumn{2}{|c|}{$\mathbf{N}_{2} \mathbf{O}$} & \multicolumn{2}{|c|}{$\mathrm{CO}_{2}$} \\
\hline & Average & SD & Average & SD & Average & SD \\
\hline & \multicolumn{2}{|c|}{$-\mathrm{gCha}^{-1} \mathrm{yr}^{-1}$} & \multicolumn{2}{|c|}{$\begin{array}{l}-\mathrm{gNha}^{-1} \mathrm{yr}^{-1}- \\
\underline{2002}\end{array}$} & \multicolumn{2}{|c|}{$-\mathrm{kgCha}^{-1} \mathrm{yr}^{-1}$} \\
\hline CT-CC-0 & 267 & 84 & 375 & 75 & 4864 & 368 \\
\hline CT-CC-134 & 299 & 180 & 970 & 190 & 4815 & 236 \\
\hline CT-CC-202 & 392 & 116 & 1298 & 230 & 4513 & 574 \\
\hline NT-CC-0 & 344 & 86 & 233 & 67 & 3440 & 281 \\
\hline NT-CC-134 & 223 & 120 & 698 & 72 & 3647 & 356 \\
\hline NT-CC-202 & 370 & 140 & 940 & 395 & 3601 & 558 \\
\hline NT-CB-0 & 289 & 107 & 611 & 91 & 3682 & 483 \\
\hline NT-CB-202 & 335 & 177 & 1605 & 483 & 3563 & 353 \\
\hline \multicolumn{7}{|c|}{$\underline{2003}$} \\
\hline CT-CC-0 & 49 & 207 & 247 & 61 & 3548 & $\mathbf{3 1 7}$ \\
\hline CT-CC-134 & $-\mathbf{3 3}$ & 234 & 2616 & 1257 & 3730 & 816 \\
\hline CT-CC-224 & -151 & 59 & 3563 & 667 & 3661 & 681 \\
\hline NT-CC-0 & -27 & 59 & 209 & 28 & 3188 & 261 \\
\hline NT-CC-134 & -56 & 91 & 1374 & 281 & 3520 & 542 \\
\hline NT-CC-224 & -88 & 51 & 2984 & 1822 & 3534 & 645 \\
\hline NT-CB-0 & -53 & 52 & 228 & 67 & $\S$ & $\S$ \\
\hline NT-CB-56 & -105 & 101 & 599 & 237 & $\S$ & $\S$ \\
\hline \multicolumn{7}{|c|}{2004} \\
\hline CT-CC-0 & -87 & 56 & 460 & 130 & 3572 & 545 \\
\hline CT-CC-134 & -111 & 85 & 864 & 272 & 3252 & 752 \\
\hline CT-CC-224 & -96 & 86 & 1461 & 320 & 2876 & 455 \\
\hline NT-CC-0 & -64 & 15 & 223 & 88 & 3369 & 321 \\
\hline NT-CC-134 & -95 & 46 & 1201 & 616 & 3890 & 568 \\
\hline NT-CC-224 & -94 & 21 & 1451 & 739 & 3399 & 719 \\
\hline NT-CB-0 & -106 & 57 & 846 & 411 & 3770 & 773 \\
\hline NT-CB-224 & -128 & 81 & 2137 & 640 & 3619 & $\mathbf{7 5 0}$ \\
\hline
\end{tabular}

$\dagger$ Annual estimates were made from linear interpolation between measured points in time and summing daily calculated values for the entire year. Standard deviations are for six measurement replicates of yearly totals.

$\$$ CT-CC, conventional-till continuous corn; NT-CB, no-till corn-soybean rotation; NT-CC, no-till continuous corn. The number refers to fertilizer rate $\left(\mathrm{kg} \mathrm{N} \mathrm{ha}^{-1}\right)$.

$\S$ Values are not presented because soybean plants were kept within chamber areas during the entire growing season and are not comparable to other respiration values.

following plowing and remained higher than fluxes from NT soils until crop planting at the end of April (Fig. 5). During 2003-2004 fallow season, crop rotation did not measurably affect $\mathrm{CO}_{2}$ emissions in NT soils. The $\mathrm{CO}_{2}$ flux rates tended to be lower in CT soils in 2003-2004 than in 2002-2003 $(P<0.01)$ while the reverse was the case for all NT treatments. The reason for this apparent reversal of trends in $\mathrm{CO}_{2}$ emissions during the fallow seasons is unknown. One possibility is that the NT soils are approaching a steady state relative to changes in SOC content. As SOC accrual decreases, $\mathrm{CO}_{2}$ emissions would tend to increase relative to $\mathrm{CT}$ soils. The $\mathrm{CO}_{2}$ exchange rates were not influenced by differences in fertilizer $\mathrm{N}$ rates $(P>0.2)$.

Carbon dioxide flux from the soil is largely due to biological processes, although inorganic processes such as dissolution of carbonates due to soil acidification can also serve as a source of atmospheric $\mathrm{CO}_{2}$ (Robertson et al., 2000). Typically, $\mathrm{CO}_{2}$ flux from soil is recognized as the result of two processes: root respiration and decomposition of organic materials by soil micro- and macrofauna. Decomposition of organic matter is performed by the soil biota, and predominately by soil microorganisms. The main factors controlling soil microbial activity include temperature, water, oxygen content, substrate availability, and substrate quality. The contributions of these factors



Fig. 4. Average soil-atmosphere exchange rates of $\mathrm{CH}_{4}$ during (A) the 2002, 2003, and 2004 growing seasons; and (B) during the fallow seasons, November-April of 2002-2004. Note the different scales for $\mathrm{CH}_{4}$ flux.

are influenced by factors such as location in the landscape, vegetation type, soil texture, and management.

Root respiration results in the release of $\mathrm{CO}_{2}$ from the metabolism of plant root cells, although because of methodological problems, it is difficult to determine root cell derived $\mathrm{CO}_{2}$ from the $\mathrm{CO}_{2}$ derived from decomposition of root exudates in the rhizosphere. Thus, these two processes are often not distinguished in discussions of root respiration (Wiant, 1967). The contribution of root respiration to total soil respiration is dependant on vegetation type, growing patterns, season, soil, climate, and management conditions. Rochette et al. (1999) reported that for maize in eastern Canada, root respiration was zero over the first $30 \mathrm{~d}$ from planting, but during the next $30 \mathrm{~d}$ of plant growth the contribution of root respiration increased linearly to a maximum of $45 \%$ where it remained constant until plant senescence. Total soil $\mathrm{CO}_{2}$ flux during the 160 -d period from planting to harvest was $5.5 \mathrm{Mg} \mathrm{CO}_{2}-\mathrm{C} \mathrm{ha}^{-1}$, with root respiration accounting for $28.7 \%$ of this total seasonal soil respiration (Rochette et al., 1999). We used a root respiration contribution of $30 \%$ of the total growing season $\mathrm{CO}_{2}$ efflux in our estimates of $\mathrm{CO}_{2}$ efflux from soil respiration (Tables 2 and 4 ).

Seasonal changes in $\mathrm{CO}_{2}$ flux have been reported to follow seasonal temperature trends (Anderson, 1973; 




Fig. 5. Soil-atmosphere exchange of $\mathrm{CO}_{2}$ from (A) unfertilized conventional-till continuous corn (CT-CC), no-till continuous corn (NT-CC), and no-till corn-soybean rotation (NT-CB) plots; (B) CTCC and NT-CC plots fertilized with $134 \mathrm{~kg} \mathrm{~N} \mathrm{ha}^{-1}$; and (C) CT-CC and NT-CC plots fertilized with $202 \mathrm{~kg} \mathrm{~N} \mathrm{ha}^{-1}$ in 2002 and $224 \mathrm{~kg} \mathrm{~N}$ $\mathrm{ha}^{-1}$ in 2003 and 2004, and NT-CB plots fertilized with 202, 56, and $224 \mathrm{~kg} \mathrm{~N} \mathrm{ha}^{-1}$ in 2002 (corn year), 2003 (soybean year), and 2004 (corn year), respectively.

Buyanovsky et al., 1987; Franzluebbers et al., 2002; Raich and Tufekcioglu, 2000; Rochette et al., 1991). On a shorter time scale, diurnal changes in soil $\mathrm{CO}_{2}$ flux generally follow soil temperature (Akinremi et al., 1999; Parkin and Kaspar, 2003), with maximum $\mathrm{CO}_{2}$ fluxes occurring in the mid-afternoon, and minimum fluxes occurring in the early morning.

In long-term experiments it has been generally observed that as $\mathrm{C}$ inputs to soil increase, soil organic matter increases (Jenkins, 1991; Paustian et al., 1995). Substrate availability is not only a function of $\mathrm{C}$ inputs, but is also related to accessibility. Carbon accessibility in


Fig. 6. Soil-atmosphere exchange of $\mathrm{CO}_{2}$ during (A) the 2002, 2003, and 2004 growing seasons (May-October); and (B) during the fallow seasons (November-April) 2002-2003 and 2003-2004. Note the different scales for seasonal $\mathrm{CO}_{2}$ flux.

soil is influenced by three mechanisms: (i) physical protection, (ii) chemical stabilization, and (iii) biochemical resistance (Christensen, 1996). Physically protected $\mathrm{C}$ is material trapped inside of soil aggregates that is not accessible to microbial action (Tisdall and Oades, 1982; Elliott, 1986; Beare et al., 1994; Jastrow and Miller, 1997). Chemically stabilized $C$ is in the form of organic matter bound to soil, especially clays (Tisdall, 1996; Christensen, 1996). Biochemical availability relates to the susceptibility of organic materials to enzymatic attack (Paul and Clark, 1989).

\section{Soil Carbon Change}

While terrestrial systems represent a major source of $\mathrm{CO}_{2}$ to the atmosphere, measurements of soil $\mathrm{CO}_{2}$ fluxes alone are not necessarily indicative of atmospheric

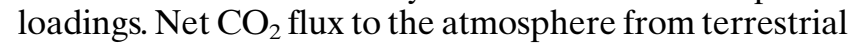
systems represents the balance between $\mathrm{C}$ inputs by autotrophic fixation and outputs by heterotrophic oxidation of organic material. Measurement of soil $\mathrm{CO}_{2}$ flux will not distinguish net $\mathrm{CO}_{2}$ flux to the atmosphere. Net $\mathrm{CO}_{2}$ flux to the atmosphere can be determined from changes in storage. However, small annual changes coupled with high spatial variability usually restrict such measurements to long-term monitoring. Total $\mathrm{C}$ input is difficult to measure as well because of the difficulty in quantifying root biomass in the field. 
Rochette et al. (1999) observed that soil $\mathrm{CO}_{2}$ fluxes varied between approximately 2 and $6 \mathrm{~g} \mathrm{CO}_{2}-\mathrm{C} \mathrm{m}^{-2} \mathrm{~d}^{-1}$ during the growing season in a corn field located near Ottawa, Ontario, Canada. Parkin and Kaspar (2003) observed similar $\mathrm{CO}_{2}$ emissions from the soil from a corn field located near Boone, Iowa, during Days 63 158 of the year. The $\mathrm{CO}_{2}$ flux rates from both CT and NT soils during the growing season were of similar magnitude (Fig. 5) in our study to those reported by Rochette et al. (1999) and Parkin and Kaspar (2003). The soil-atmosphere exchange of $\mathrm{CO}_{2}$ that we observed followed the same seasonal temperature patterns, with the highest fluxes typically associated with the highest temperatures (Fig. 1 and 5). During the 2002 growing season $\mathrm{CO}_{2}$ flux was greater than in 2003 and 2004 from CT soils, and was greater from CT than NT soils in 2002. During the following two growing seasons, there were no significant differences between CT and NT soil $\mathrm{CO}_{2}$ emissions (Fig. 6A; Table 2).

During the two fallow seasons, $\mathrm{CO}_{2}$ flux was generally higher from CT than NT soils (Fig. 6B). Fluxes from CT tended to be higher during the 2002-2003 fallow season than during the following years. For all NT soils, the reverse trend was the case. Reasons for the reverse trend by year and tillage are not clear. Possibly the NT soil C accumulation is slowing with time after conversion from CT to NT. If the NT soils are approaching a steady state of SOC content after 4 to $5 \mathrm{yr}$ of NT then $\mathrm{CO}_{2}$ emissions would tend to be progressively more similar to those from CT. The CENTURY model predicts such trends for NT systems as they mature (Del Grosso et al., 2002).

\section{Nitrous Oxide}

Nitrous oxide fluxes quickly increased each year, days to weeks following $\mathrm{N}$ fertilization. Fluxes were highest the month following fertilization then declined to background levels in early autumn (Fig. 7). Differences of flux intensity between years is evident, with 2002 and 2004 being lower than 2003 (Fig. 7; Table 2).

\section{Year}

In CT-CC soils, $\mathrm{N}_{2} \mathrm{O}$ fluxes were significantly higher from all $\mathrm{N}$-fertilized plots during 2003 than in 2002 or $2004(P<0.01)$ (Table 2$)$. The $\mathrm{N}_{2} \mathrm{O}$ flux rates from NT$\mathrm{CC}$ fertilized plots were significantly higher $(P<0.05)$ in 2003 than in 2002 but were not different between 2002 and 2004. In CT-CC and NT-CC unfertilized plots, $\mathrm{N}_{2} \mathrm{O}$ emission rates did not differ across years, while $\mathrm{N}_{2} \mathrm{O}$ fluxes from the NT-CB unfertilized plots were significantly lower during 2003, the soybean phase of the rotation, than in 2002 or 2004, the corn phase of the crop rotation (Fig. 8A).

\section{Tillage}

Nitrous oxide fluxes from unfertilized CT-CC soils were small, yet were significantly greater $(P<0.05)$ than from NT-CC soils during all three growing seasons. During 2002, $\mathrm{N}_{2} \mathrm{O}$ fluxes trended higher in CT-CC soils fertilized at the same rate compared to NT-CC treat-



Fig. 7. Nitrous oxide flux rate observations made during 28 Apr. 2002 through 28 Oct. 2004 from (A) unfertilized conventional-till continuous corn (CT-CC), no-till continuous corn (NT-CC), and no-till corn-soybean rotation (NT-CB) plots; (B) CT-CC and NT-CC plots fertilized with $134 \mathrm{~kg} \mathrm{~N} \mathrm{ha}^{-1} \mathrm{yr}^{-1}$; and (C) CT-CC and NT-CC plots fertilized with 202, 224, and $224 \mathrm{~kg} \mathrm{~N} \mathrm{ha}^{-1}$ in 2002, 2003, and 2004, respectively, and NT-CB plots fertilized with 202,56 , and $224 \mathrm{~kg} \mathrm{~N}$ $h^{-1}$ in 2002 (corn year), 2003 (soybean year), and 2004 (corn year), respectively. Note the different scales.

ments and were significantly higher in $2003(P<0.01)$ (Tables 2 and 3). In 2004, $\mathrm{N}_{2} \mathrm{O}$ flux rates trended higher, but not significantly in the NT-CC fertilized plots compared to the CT-CC fertilized plots. Tillage effects were different each of the three growing seasons of the study. In 2002, $\mathrm{N}_{2} \mathrm{O}$ emissions from CT-CC plots averaged higher, but not significantly, than from NTCC plots, while in 2003, emissions were statistically higher from the CT-CC plots. In 2004, $\mathrm{N}_{2} \mathrm{O}$ emissions were higher from the NT-CC plots compared to the CT$\mathrm{CC}$ treatments $(P<0.1)$. Averaged over the whole three 




Fig. 8. Seasonal averaged $\mathrm{N}_{2} \mathrm{O}$ fluxes during (A) the 2002, 2003, and 2004 growing seasons from plots fertilized at the rates of 0,134 , and 202 or $224 \mathrm{~kg} \mathrm{~N} \mathrm{ha}^{-1}$ in conventional-till continuous corn (CT-CC) and no-till continuous corn (NT-CC) plots and 0 and 202, 0 and 56, and 0 and $224 \mathrm{~kg} \mathrm{~N} \mathrm{ha}^{-1}$ in no-till corn-soybean rotation (NT-CB) plots in 2002 (corn year), 2003 (soybean year), and 2004 (corn year), respectively; and (B) the November through April 2002-2003 and 2003-2004 fallow seasons. Note the different scales.

years, growing season emission rates were similar, but significantly $(P<0.1)$ higher in CT-CC because of the large difference between the fluxes in 2003 .

\section{Crop Rotation}

During the corn phase of the corn-soybean rotation (NT-CB-0, 2002, and 2004) the apparent $\mathrm{N}$ input from the previous year soybean production raised background $\mathrm{N}_{2} \mathrm{O}$ emissions by approximately $90 \%$ compared to CTCC-0 and more than $300 \%$ compared to NT-CC-0. The $\mathrm{N}_{2} \mathrm{O}$ fluxes from both the no- $\mathrm{N}$ and high $\mathrm{N}$ fertilizer rate plots were significantly greater $(P<0.05)$ than from the NT-CC plots that were fertilized at the same rates (Fig. 8A; Tables 2 and 3 ). Enhanced $\mathrm{N}_{2} \mathrm{O}$ flux rates averaged approximately $15 \mu \mathrm{g} \mathrm{N} \mathrm{m}{ }^{-2} \mathrm{~h}^{-1}$ when no fertilizer $\mathrm{N}$ was added and 15 to $20 \mu \mathrm{g} \mathrm{N} \mathrm{m}^{-2} \mathrm{~h}^{-1}$ during the growing season when the highest rates of $\mathrm{N}$ were added.

During the fallow seasons, $\mathrm{N}_{2} \mathrm{O}$ fluxes were not affected by $\mathrm{N}$ fertilization from the previous spring $\mathrm{N}$ application in either CT or NT soils (Fig. 8B). There were also no differences between the different tillage treatments during the 2002-2003 fallow season. During the
2003-2004 fallow season, $\mathrm{N}_{2} \mathrm{O}$ flux rates from CT soils were approximately double those from NT soils. In the NT plots $\mathrm{N}_{2} \mathrm{O}$ flux rates trended higher in 2002-2003.

\section{Nitrogen Rate}

Nitrous oxide production and emissions from soil are regulated, mainly, by substrate availability, soil water content, and temperature (Dobbie et al., 1999). The influence of each of these factors on the microbial processes of nitrification and denitrification, by which $\mathrm{N}_{2} \mathrm{O}$ is produced, is generally, individually, well known. It is the interaction of these factors with physical conditions such as soils, management, and timing of weather events that influence, not only production, but also diffusion of $\mathrm{N}_{2} \mathrm{O}$ through and out of the soil that is not yet well understood. Year-to-year variability of $\mathrm{N}_{2} \mathrm{O}$ emissions from fields that were managed the same way each year can be high (Dobbie et al., 1999). This was the case for our study as well (Fig. 7, 8, and 9).

Although the slope varied, the $\mathrm{N}_{2} \mathrm{O}$ flux rates were linearly proportional to $\mathrm{N}$ fertilizer rates (Fig. 9A, 9B, and 9C). The CT-CC response to $\mathrm{N}$ was $1.1,3.9$, and $1.5 \mu \mathrm{g}$ $\mathrm{N}_{2} \mathrm{O}-\mathrm{N} \mathrm{m}^{-2}$ compared to $1.0,3.2$, and $2.0 \mu \mathrm{g} \mathrm{N}_{2} \mathrm{O}-\mathrm{N} \mathrm{m}^{-2}$ in NT-CC for 2002, 2003, and 2004, respectively (Fig. 9A, $9 \mathrm{~B}$, and 9C). The annual $\mathrm{N}_{2} \mathrm{O}$ emissions from $\mathrm{N}$-fertilized NT and CT plots were 1.9 to 3.2 times greater in 2003 than in 2002 (Tables 2 and 3). In 2004, total $\mathrm{N}_{2} \mathrm{O}$ annual emissions were 0.9 to 1.2 times higher than in 2002 from CT plots and 1.6 to 1.8 times greater in NT plots (Tables 2 and 3 ). The variability in annual $\mathrm{N}_{2} \mathrm{O}$ emission was reflected in significant tillage-by-year and $\mathrm{N}$ rate-by-year interactions (Table 3). In 2002 tillage did not significantly affect $\mathrm{N}_{2} \mathrm{O}$ flux, while in $2003 \mathrm{~N}_{2} \mathrm{O}$ fluxes were significantly greater from CT plots compared to NT plots $(P<$ $0.05)$. In $2004, \mathrm{~N}_{2} \mathrm{O}$ emissions were marginally greater $(P$ $<0.1$ ) from NT than from CT soils (Table 3). During the corn phase of the corn-soybean rotation $\mathrm{N}_{2} \mathrm{O}$ fluxes were significantly greater from NT-CB than from NT-CC plots for both zero and $202 / 224 \mathrm{~kg} \mathrm{~N}^{-1}$ treated plots in 2002 and 2004, respectively. Apparently residual $\mathrm{N}$ from the soybean grown the previous year became available and was utilized by $\mathrm{N}_{2} \mathrm{O}$-producing organisms to increase growing season $\mathrm{N}_{2} \mathrm{O}$ flux by about $15 \mu \mathrm{g} \mathrm{N}_{2} \mathrm{O}-\mathrm{N} \mathrm{m}^{-2} \mathrm{~h}^{-1}$. During the soybean phase of the rotation, $\mathrm{N}_{2} \mathrm{O}$ emissions were only a few $\mu \mathrm{g} \mathrm{N}_{2} \mathrm{O}-\mathrm{N} \mathrm{m} \mathrm{m}^{-2} \mathrm{~h}^{-1}$ higher than comparably fertilized NT-CC soils $(P<0.1)$ (Fig. 8 and 9$)$.

Nitrous oxide fluxes were higher in NT than in CT in the studies in England and Canada, discussed in Six et al. (2004), but were not different in the Nebraska (Kessavalou et al., 1998) and Michigan (Robertson et al., 2000) studies. Soil moisture was likely continually higher at the sites where $\mathrm{N}_{2} \mathrm{O}$ emissions were higher in NT, but the fields in England and Canada had been converted to NT less than $10 \mathrm{yr}$ before the studies were conducted. Tillage had little effect on soil $\mathrm{CH}_{4}$ consumption or $\mathrm{N}_{2} \mathrm{O}$ emissions in the semiarid wheat-fallow system in Nebraska or the crop rotation studies in more humid Michigan. The Nebraska and Michigan sites had been converted to NT 20 and $10 \mathrm{yr}$, respectively, before the gas flux measurements were made. 


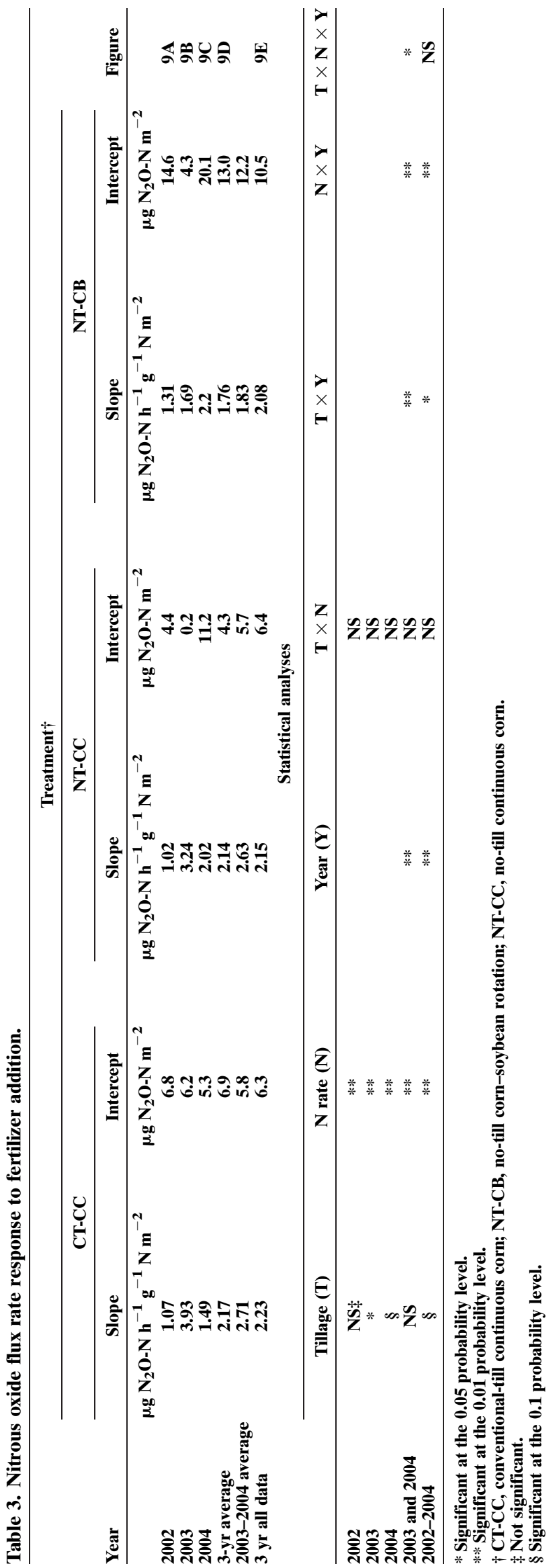

\section{Net Global Warming Potential and Greenhouse Gas Intensity Estimates}

The overall balance between the net exchange of $\mathrm{CO}_{2}$, $\mathrm{CH}_{4}$, and $\mathrm{N}_{2} \mathrm{O}$ constitutes the net global warming potential (GWP) of a cropping system. Storage of atmospheric $\mathrm{CO}_{2}$ into stable organic carbon pools in the soil can sequester $\mathrm{CO}_{2}$, while commonly used irrigated crop production practices generate $\mathrm{CO}_{2}$ and $\mathrm{N}_{2} \mathrm{O}$ and decrease the soil sink for atmospheric $\mathrm{CH}_{4}$. Typically, agricultural soils are minor emitters of $\mathrm{CH}_{4}$ and generally small sinks for atmospheric $\mathrm{CH}_{4}$ (Bronson and Mosier, 1993). Nitrous oxide, the principal non- $\mathrm{CO}_{2}$ greenhouse gas emitted from soils, is produced naturally in the soil through nitrification and denitrification (Robertson et al., 2000). Nitrogen fertilizer input to facilitate crop production augments this production. It is the relationship of soil $\mathrm{C}$ changes to $\mathrm{N}_{2} \mathrm{O}$ emissions that typically regulates net GWP (Robertson et al., 2000). In addition to the fluxes of greenhouse gases, the energy used to pump irrigation water; for farm operations such as plowing, planting, and harvesting; and for producing fertilizer are included in the GWP estimate (Robertson et al., 2000; Mosier et al., 2005). We relate GWP to crop production by dividing net GWP by crop produced on an area basis to estimate the greenhouse gas intensity (GHGI) of a production system.

\section{Global Warming Potential}

Measurement of the change of SOC is the typical way in which $\mathrm{CO}_{2}$ exchange is estimated (Robertson et al., 2000). An estimate of net GWP for the April 2002March 2003 period using estimates of SOC from soil C measurements for CT-CC and NT-CC plots indicated that all NT-CC plots were net sinks of GWP and all CTCC plots were net sources (Mosier et al., 2005). The soil estimate did not distinguish differences in SOC changes between $\mathrm{N}$ rates, even though biomass production was about 1.5 times greater when 134 or $224 \mathrm{~kg} \mathrm{~N} \mathrm{ha}^{-1}$ was added compared to the no-N plots. The SOC values were calculated as the annual loss (or gain) in soil organic $\mathrm{C}$ content in the 0 - to $7.5-\mathrm{cm}$ depth estimated by linear regression of all CT-CC or NT-CC plots between 1999 and 2002 (Mosier et al., 2005). Using those SOC estimates, the zero-N plots showed the greatest net gain in GWP (smallest values) within tillage treatments. The data presented in Table 4 contain SOC data that are based on linear regression of CT-CC or NT-CC plot SOC measurements made between 1999 and 2004 for the specified $\mathrm{N}$ fertilizer rates. As expected for NT soils, SOC is increasing with increasing $\mathrm{N}$ rate because crop residue production increased with $\mathrm{N}$ rate each year. Soil SOC changes were estimated the same way for CT soils and observed changes were smaller than in NT, and the changes do not readily reflect fertilizer $\mathrm{N}$ input rates. Using the SOC method for calculating net GWP, the CT soils were always net sources of $\mathrm{CO}_{2}$ while NT soils were always net sinks (Fig. 10A; Table 4). The NT-CB rotation was a net source of GWP during the corn phase of the corn-bean rotation and a small net sink of GWP during the bean part of the rotation (Table 4). 



Fig. 9. Effect of $\mathrm{N}$ fertilizer rate on growing season $\mathrm{N}_{2} \mathrm{O}$ emissions in (A) 2002, (B) 2003, (C) 2004, (D) three-year average, and (E) all three years of data. Note the different scales.

During the corn part of the $\mathrm{CB}$ rotation $\mathrm{N}_{2} \mathrm{O}$ emissions were higher than from continuous corn plots.

We present a second method of estimating net GWP (Fig. 10B; Table 4) where we calculate net $\mathrm{CO}_{2}$ exchange by using measured soil respiration values and aboveground crop residue input (Hanson et al., 2000; Rochette et al., 1999). The seasonal and yearly $\mathrm{CO}_{2}$ emission totals were calculated by linear interpolation between measured values, and summing the total of daily $\mathrm{CO}_{2}$ flux estimates. We estimated the amount of $\mathrm{CO}_{2}$ evolved from soil organic matter and crop residue decomposition during the growing season by multiplying growing season $\mathrm{CO}_{2}$ emission by 0.7 to remove the contribution of total $\mathrm{CO}_{2}$ evolution due to root respiration (Rochette et al., 1999), then subtracting this value from the crop residue input from the previous year. For example, for 2002, we used the amount of crop residue that was returned to the soil at harvest in November 2001 (Table 4). The 2001 residue production was large and total $\mathrm{C}$ from residue generally exceeded total $\mathrm{CO}_{2}$ emission from the decomposition of soil organic matter and plant residue in 2002. As noted in the discussion of the $\mathrm{CO}_{2}$ flux data above, measured soil respiration rates did not differ with $\mathrm{N}$ rate, even though considerably more crop residue (Halvorson et al., 2006) was returned to the soil the year before in N-fertilized plots compared to where no $\mathrm{N}$ fertilizer was applied. Differences in root residues may have influenced these measurements, but no data are available to quantitatively measure their impact at any given time. The same 
MOSIER ET AL.: GWP AND GHGI IN IRRIGATED CROPPING SYSTEMS OF COLORADO








Fig. 10. Net global warming potential calculated $(A)$ from changes in soil organic carbon (SOC) from 1999 to 2004; and (B) from soil respiration and crop residue input data for the conventional-till continuous corn (CT-CC) and no-till continuous corn (NT-CC) 0 , 134, and high $\mathbf{N}(\mathrm{HN}) \mathrm{kg} \mathrm{N}^{\mathrm{N}} \mathrm{ha}^{-1} \mathrm{~N}$ rate treatments. Note the different scales.

amount of irrigation water was applied to all plots for a particular year and the same energy estimate by tillage was used across years, so across tillage and $\mathrm{N}$ rate the variables of importance that changed were energy used to manufacture $\mathrm{N}$ fertilizer, $\mathrm{N}_{2} \mathrm{O}$ emissions, and crop residue input. Soil respiration was greater in CT plots than from NT plots in 2002, but was not different across treatments or years in 2003 and 2004. Residue input exceeded respiration output in all NT plots in 2002, in only the N-fertilized plots in 2003, and in only the plots fertilized with $224 \mathrm{~kg} \mathrm{~N} \mathrm{ha}^{-1}$ in 2004. Unfertilized CT soils were a net source of $\mathrm{CO}_{2}$ in all years while increased residue production in fertilized soils offset the increased $\mathrm{N}_{2} \mathrm{O}$ emissions. The result was a small net sink of GWP in CT soils in both 2003 and 2004. In 2003 and 2004 net GWP was greater in soils fertilized with the highest $\mathrm{N}$ rate, because crop residue production was the same in both 134 and $224 \mathrm{~kg} \mathrm{~N}^{-1}$ plots, while $\mathrm{N}_{2} \mathrm{O}$ emissions were much greater with the highest $\mathrm{N}$ rate. The NT plots were a net source of GWP when no N was added because of the low levels of biomass production. The $224 \mathrm{~kg} \mathrm{~N}^{-1}$ plots were net GWP sinks in all three years while the $134 \mathrm{~kg} \mathrm{~N}^{-1}$ plots were net GWP sources in 2004 because of the low biomass production in 2003 and relatively high $\mathrm{N}_{2} \mathrm{O}$ production (Tables 3 and 4). For the NT-CB plots during the 2002 and 2004 corn part of the rotation, net GWP is much larger than in the NT-CC and CT-CC plots because the bean residue input from the year before is much smaller than the corn residue. As a result, the NT-CB plots were calculated to be a large source for GWP.

The two methods for estimating net GWP provide different views. The SOC technique is based on SOC measurements. These values are subject to error due to spatial variability and interference from inorganic $\mathrm{C}$, even though repeatability of analyses on the same soil samples is very $\operatorname{good}( \pm 1 \%$ of the same soil sample). The soil respiration measurements also suffer from spatial as well as temporal variability problems. In making the respiration estimate we assume that day-to-day and hour-byhour variability in $\mathrm{CO}_{2}$ evolution from soils is captured in our measurements, as Rochette et al. (1999) suggest. The results from the 2002 respiration technique calculation suggest that soils were a much larger sink for $\mathrm{CO}_{2}$ than estimated by the SOC technique, and that $\mathrm{N}$-fertilized CT soils were net $\mathrm{CO}_{2}$ sinks as well (Table 4). In 2004, the respiration data suggest that the soil C accrual rate in NT was slowing, relative to 2002 and 2003, in the 0 and $134 \mathrm{~N}$ rates. These observations coincide with other changes, such as a tendency for higher $\mathrm{N}_{2} \mathrm{O}$ emission rates from NT compared to $\mathrm{CT}$ in 2004 and lower $\mathrm{CO}_{2}$ soil-atmosphere exchange rates in CT in 2004 compared to NT.

\section{Greenhouse Gas Intensity}

The GHGI relates GWP to crop production. As with GWP, positive values expressed as $\mathrm{kg} \mathrm{CO}_{2}$ equivalents per $\mathrm{kg}$ of corn grain produced indicate a net source of GHGs to the atmosphere while negative values indicate net sinks of GHG to the soil. Using the SOC estimates to calculate GHGI resulted in all NT systems being a net sink for $\mathrm{CO}_{2}$ and all CT soils being a net source, as with GWP. Using the soil respiration estimates in 2002, only the high $\mathrm{N}$ rate of CT-CC plots decreased atmospheric $\mathrm{CO}_{2}$ per unit of corn produced, while all NT plots were $\mathrm{CO}_{2}$ sinks (Tables 4 and 5). In 2003, both the CT-134 and

Table 5. Statistical analysis of global warming potential (GWP) and greenhouse gas intensity (GHGI) data from Table 4. Effect of tillage, $N$ rate, and year on GWP and GHGI.

\begin{tabular}{|c|c|c|c|c|c|c|c|}
\hline Year & $\begin{array}{c}\text { Tillage } \\
\text { (T) }\end{array}$ & $\begin{array}{c}\text { N rate } \\
\text { (N) }\end{array}$ & $\mathbf{T} \times \mathbf{N}$ & $\begin{array}{l}\text { Year } \\
(\mathbf{Y})\end{array}$ & $\mathbf{T} \times \mathbf{Y}$ & $\mathbf{N} \times \mathbf{Y}$ & $\mathbf{T} \times \mathbf{N} \times \mathbf{Y}$ \\
\hline \multicolumn{8}{|c|}{2002} \\
\hline GWP & $* * *$ & $* * *$ & $* *$ & $\mathbf{N A} \dagger$ & NA & NA & NA \\
\hline GHGI & $* * *$ & $* * *$ & $* * *$ & NA & NA & NA & NA \\
\hline \multicolumn{8}{|c|}{$\underline{2003}$} \\
\hline GWP & * & $* *$ & NS & $\mathbf{N A}$ & NA & NA & NA \\
\hline GHGI & * & $* *$ & NS & $\mathbf{N A}$ & NA & NA & NA \\
\hline \multicolumn{8}{|c|}{2004} \\
\hline GWP & $* *$ & $* * *$ & $* *$ & NA & NA & NA & NA \\
\hline GHGI & ** & $* * *$ & $* *$ & NA & NA & NA & $\mathbf{N A}$ \\
\hline \multicolumn{8}{|c|}{ 2002-2004 } \\
\hline GWP & $* * *$ & $*$ & $* * *$ & $* * *$ & $* * *$ & $* * *$ & $* * *$ \\
\hline GHGI & $* * *$ & $* * *$ & $* * *$ & $* *$ & $* * *$ & $* * *$ & $* * *$ \\
\hline
\end{tabular}

* Significant at the 0.05 probability level.

** Significant at the 0.01 probability level.

*** Significant at the 0.001 probability level.

$\dagger$ Analysis not applicable. 
CT-224 N rates were small consumers of GHGs (0.1 to $0.15 \mathrm{~kg} \mathrm{CO}$ equivalents per $\mathrm{kg}$ of corn produced). This was similar to the NT sink size. In 2004, the GHGI in the $\mathrm{N}$-fertilized CT plots was not significantly different from zero while the $134 \mathrm{~N}$ rate of the NT plots was a net $\mathrm{CO}_{2}$ source. The highest NT-N rate, because of the higher corn yield, was a net GHGI sink. These estimates for both GWP and GHGI indicate that when appropriate crop production levels are achieved, net $\mathrm{CO}_{2}$ emissions are reduced. The results suggest that economic viability and environmental conservation can be achieved by the utilization of appropriate levels of fertilizer.

\section{CONCLUSIONS}

These multi-year data suggest that there is year-toyear variability in trace gas exchange, as demonstrated by Dobbie et al. (1999) in other systems and inter-annual variability in SOC exchange as well. The data also suggest the possibility of two trends in the NT-CC system. First, the $\mathrm{N}_{2} \mathrm{O}$ flux rates relative to $\mathrm{CT}-\mathrm{CC}$ may be changing, from tending to be lower in NT-CC to higher. Second, measured $\mathrm{CO}_{2}$ respiration rates were higher in $\mathrm{CT}$ in 2002 but were not measurably different in either 2003 or 2004. Both the $\mathrm{N}_{2} \mathrm{O}$ and $\mathrm{CO}_{2}$ flux trends suggest that the rate of SOC accumulation in the NT plots is slowing and that the system is approaching steady state as predicted for NT by DAYCENT simulations (Del Grosso et al., 2002). Although the trends in GWP appear to be best described by DAYCENT simulations rather than the Six et al. (2004) projections, further confirmation of long-term trends is needed. This data need may be addressed either by continuing to make observations for several years or by initiating a multiple year set of observations after the site has been under no-till for at least 10 years.

\section{ACKNOWLEDGMENTS}

We thank A. Kear, W. Morgan, M. Smith, G. Smith, S. Crookall, P. Norris, C. Cannon, and B. Floyd for their technical assistance. We also acknowledge the financial support of USDA-ARS, USDA-CSREES-NRI (Grant \#2001-3510810719), and USDA-CSREES-CASMGS (Grant Agreement no. 2001-38700-11092). X.J. Liu was supported by the National Natural Science Foundation of China (Grant \#30370287 and 30390080) as well as the Key Import Project of Chinese Ministry of Agriculture (Grant \#202003-Z53).

\section{REFERENCES}

Akinremi, O.O., S.M. McGinn, and H.D.J. McLean. 1999. Effects of soil temperature and moisture on soil respiration in barley and fallow plots. Can. J. Soil Sci. 79:5-13.

Analytical Software. 2005. Statistix 8.0. Analytical Software, Tallahassee, FL.

Anderson, J.M. 1973. Carbon dioxide evolution from two temperate, deciduous woodland soils. J. Appl. Ecol. 10:361-378.

Beare, M.H., M.L. Cabrera, P.F. Hendrix, and D.C. Coleman. 1994. Aggregate-protected and unprotected organic matter pools in conventional- and no-tillage soils. Soil Sci. Soc. Am. J. 58:787-795.

Bronson, K.F., and A.R. Mosier. 1993. Nitrous oxide emissions and methane consumption in wheat and corn-cropped systems in northeastern Colorado. p. 133-144. In L.A. Harper et al. (ed.)
Agricultural ecosystem effects on trace gases and global climate change. ASA Spec. Publ. 55. ASA, Madison, WI.

Buyanovsky, G.A., C.L. Kucera, and G.H. Wagner. 1987. Comparative analyses of carbon dynamics in native and cultivated ecosystems. Ecology 68:2023-2031.

Chan, A.S.K., and T.B. Parkin. 2001. Methane oxidation and production activity in soils from natural and agricultural ecosystems. J. Environ. Qual. 30:1896-1903.

Christensen, B.T. 1996. Carbon in primary and secondary organomineral complexes. Adv. Soil Sci. 8:97-165.

Cole, C.V., J. Duxbury, J. Freney, O. Heinemeyer, K. Minami, A. Mosier, K. Paustian, N. Rosenberg, N. Sampson, D. Sauerbeck, and Q. Zhao. 1997. Global estimates of potential mitigation of greenhouse gas emissions by agriculture. Nutr. Cycling Agroecosyst. 49: 221-228.

Council for Agricultural Science and Technology. 2004. Climate change and greenhouse gas mitigation: Challenges and opportunities for agriculture. Task Force Rep. 141. CAST, Ames, IA.

Delgado, J.A., and A.R. Mosier. 1996. Mitigation alternatives to decrease nitrous oxide emissions and urea-nitrogen loss and their effect on methane flux. J. Environ. Qual. 25:1105-1111.

Del Grosso, S.J., D.S. Ojima, W.J. Parton, and A.R. Mosier. 2002 Simulated effects of tillage and timing of $\mathrm{N}$ fertilizer application on net greenhouse gas fluxes and $\mathrm{N}$ losses from agricultural soils in the Midwestern USA. p. 23-29. In Van Ham et al. (ed.) Non- $\mathrm{CO}_{2}$ greenhouse gases. Proc. NCGG 3, Maastricht, the Netherlands. 21-23 Jan. 2002. Millpress, Rotterdam, the Netherlands.

Dobbie, K.E., I.P. McTaggart, and K.A. Smith. 1999. Nitrous oxide emissions from intensive agricultural systems: Variations between crops and seasons, key driving variables, and mean emission factors. J. Geophys. Res. 104:26891-26899.

Elliott, E.T. 1986. Aggregate structure and carbon, nitrogen, and phosphorus in native and cultivated soils. Soil Sci. Soc. Am. J. 50:627-633.

Follett, R.F. 2001. Soil management concepts and carbon sequestration in cropland soils. Soil Tillage Res. 61:77-92.

Franzluebbers, K., A.J. Franzluebbers, and M.D. Jawson. 2002. Environmental controls on soil and whole-ecosystem respiration from a tallgrass prairie. Soil Sci. Soc. Am. J. 66:254-262.

Halvorson, A.D., A.R. Mosier, and C.A. Reule. 2004. Nitrogen and crop management influence irrigated corn yields and greenhouse gas emissions. p. 21-27. In A. Schlegel (ed.) Proc. 2004 Great Plains Soil Fertility Conf., Denver. 2-3 Mar. 2004. Kansas State Univ., Manhattan, KS.

Halvorson, A.D., A.R. Mosier, C.A. Reule, and W.C. Bausch. 2006 Nitrogen and tillage effects on irrigated continuous corn yields. Agron. J. 98:63-71.

Hanson, P.J., N.T. Edwards, C.T. Garten, and J.A. Andrews. 2000. Separating root and soil microbial contributions to soil respiration: A review of methods and observations. Biogeochemistry 48:115-146.

Hutsch, B.W. 1998. Tillage and land use effects on methane oxidation rates and their vertical profiles in soil. Biol. Fertil. Soils 27:284-292.

Intergovernmental Panel on Climate Change. 2001. Technical summary of the 3rd Assessment Report of Working Group 1. IPCC, Geneva.

Jastrow, J.D., and R.M. Miller. 1997. Soil aggregate stabilization and carbon sequestration: Feedbacks through organomineral associations. p. 207-223. In R. Lal et al. (ed.) Soil processes and the carbon cycle. Advances in Soil Science. CRC Press, Boca Raton, FL.

Jenkins, D.S. 1991. The Rothamsted long-term experiments: Are they still of use? Agron. J. 83:2-10.

Kessavalou, A., A.R. Mosier, J.W. Doran, R.A. Drijber, D.J. Lyon, and O. Heinemeyer. 1998. Fluxes of $\mathrm{CO}_{2}, \mathrm{~N}_{2} \mathrm{O}$ and $\mathrm{CH}_{4}$ in grass sod and winter wheat-fallow tillage management. J. Environ. Qual. 27: 1094-1104.

Kroeze, C., A.R. Mosier, and L. Bouwman. 1999. Closing the global $\mathrm{N}_{2} \mathrm{O}$ budget: A retrospective analysis 1500-1994. Global Biogeochem. Cycles 13:1-8.

Liu, X.J., A.R. Mosier, A.D. Halvorson, and F.S. Zhang. 2005. Tillage and nitrogen application effects on nitrous and nitric oxide emissions from irrigated corn fields. Plant Soil 276:235-249.

Livingston, G.P., and G.L. Hutchinson. 1995. Enclosure-based measurement of trace gas exchange: Applications and sources of error. 
p. 14-51. In P.A. Matson and R.C. Harriss (ed.) Biogenic trace gases: Measuring emissions from soil and water. Blackwell Sci., London.

Minitab. 2001. MINITAB Release 13 for Windows. Minitab, State College, PA.

Mosier, A.R., A.D. Halvorson, G.A. Peterson, G.P. Robertson, and L. Sherrod. 2005. Measurement of net global warming potential in three agroecosystems. Nutr. Cycling Agroecosyst. 72:67-76.

Mosier, A.R., J.A. Morgan, J.Y. King, D. LeCain, and D.G. Milchunas. 2002. Soil-atmosphere exchange of $\mathrm{CH}_{4}, \mathrm{CO}_{2}, \mathrm{NO}_{\mathrm{x}}$ and $\mathrm{N}_{2} \mathrm{O}$ in the Colorado shortgrass steppe under elevated $\mathrm{CO}_{2}$. Plant Soil 240: 201-211.

Mosier, A.R., D.S. Schimel, D.W. Valentine, K.F. Bronson, and W.J. Parton. 1991. Methane and nitrous oxide fluxes in native, fertilized, and cultivated grasslands. Nature 350:330-332.

Parkin, T.B., and T.C. Kaspar. 2003. Temperature controls on diurnal carbon dioxide flux: Implications for estimating soil C loss. Soil Sci. Soc. Am. J. 67:1763-1772.

Paul, E.A., and F.E. Clark. 1989. Soil microbiology and biochemistry. Academic Press, New York.

Paustian, K., G.P. Robertson, and E.T. Elliot. 1995. Management impacts on carbon storage and gas fluxes $\left(\mathrm{CO}_{2}, \mathrm{CH}_{4}\right)$ in midlatitude cropland ecosystems. p. 69-84. In R. Lal et al. (ed.) Soil management and greenhouse effect. Advances in Soil Science. CRC Press, Boca Raton, FL.

Raich, J.W., and A. Tufekcioglu. 2000. Vegetation and soil respiration: Correlations and controls. Biogeochemistry 48:71-90.

Robertson, G.P., and P.R. Grace. 2004. Greenhouse gas fluxes in tropical and temperate agriculture: The need for a full-cost accounting of global warming potentials. Environ. Development Sustainability 6:51-63.

Robertson, G.P., E.A. Paul, and R.R. Harwood. 2000. Greenhouse gases in intensive agriculture: Contributions of individual gases to the radiative forcing of the atmosphere. Science 289:1922-1925.

Rochette, P., R.L. Desjardins, and E. Pattey. 1991. Spatial and temporal variability of soil respiration in agricultural fields. Can. J. Soil Sci. 71:189-196.

Rochette, P., L.B. Flanagan, and E.G. Gregorich. 1999. Separating soil respiration into plant and soil components using analyses of the natural abundance of carbon-13. Soil Sci. Soc. Am. J. 63: $1207-1213$.

Sherrod, L.A., G. Dunn, G.A. Peterson, and R.L. Kolberg. 2002. Inorganic carbon analysis by modified pressure-calcimeter method. Soil Sci. Soc. Am. J. 66:299-305.

Six, J., S.M. Ogle, F.J. Breidt, R.T. Conant, A.R. Mosier, and K. Paustian. 2004. The potential to mitigate global warming with notillage management is only realized when practiced in the long term. Glob. Change Biol. 10:155-160.

Tisdall, J.M. 1996. Formation of soil aggregates and accumulation of soil organic matter. Adv. Soil Sci. 8:57-96.

Tisdall, J.M., and J.M. Oades. 1982. Organic matter and water-stable aggregates in soils. J. Soil Sci. 33:141-147.

USEPA. 2002. Inventory of U.S. greenhouse gas emissions and sinks: 1990-2000. EPA 236-R-00-001. USEPA, Office of Atmospheric Programs (6201J), Washington, DC.

West, T.O., and G. Marland. 2002. A synthesis of carbon sequestration, carbon emissions, and net carbon flux in agriculture: Comparing tillage practices in the United States. Agric. Ecosyst. Environ. 91: 217-232.

West, T.O., and W.M. Post. 2002. Soil organic carbon sequestration rates by tillage and crop rotation: A global data analysis. Soil Sci. Soc. Am. J. 66:1930-1946.

Wiant, H.V. 1967. Has the contribution of litter decay to forest soil respiration been overestimated? J. For. 65:408-409. 